\title{
The role of entry into regional markets in fulfilling brand promise
}

\author{
Ali Ghasemi* and Abdolhamid Hajipoor Shoshtari
}

Department of Computer Science, South Tehran Branch, Islamic Azad University, Tehran, Iran \section{H R O N I C L E}

Article history:

Received June 10, 2014

Accepted 10 November 2014

Available online

November 122014

Export

Distribution channels

Organizational capabilities

Customer satisfaction

\section{A B S T R A C T}

This paper presents an empirical investigation to study the role of entry into regional markets in fulfilling brand promise. The study designs two questionnaires, one for measuring brand promise and the other for measuring export capabilities, in Likert scale and distributes it among 250 randomly selected producers who were involved in production and development of various products in city of Esfahan, Iran. Cronbach alphas were calculated for brand promise and export capabilities as 0.856 and 0.812 , respectively. Using structural equation modeling, the study has detected seven factors including product development, public advocacy, strategic orientation, customer satisfaction, competitive pressures, organizational capabilities and distribution strategies.

\section{Introduction}

During the past few years, there have been tremendous efforts on detecting important factors for product development and export activities (Filatotchev et al., 2009; Auttarapong, 2012; Chou \& Wang, 2012). Nataghi and Nasrabadi (2014) tried to evaluate structural barriers influencing on exports of rose water and essences of Kashan to United Arabic Emirates. They reported issues associated with information infrastructure, legislative, legal and secure infrastructure, human, educational, cultural and behavioral infrastructure, infrastructure of customs, trade and taxation, internet problem, technical and hardware infrastructure and financial and software infrastructure issues were the most important factors. Mohammadi et al. (2014) determined five packaging factors influencing on export development including communications, infrastructure, awareness, design and technical extraction. Through the implementation of principal component analysis, they reported that all five packing components were effective in export development of food industry. Hosseini et al. (2014) presented a study on the effects of firm and management team's characteristics to develop food industry. The proposed study considered four factors associated with firms and 9 factors, which are related to management team's characteristics in a food industry in Iran. They reported that 
management knowledge about export market was number one important factor followed by the level of technology used, competitive advantage, believe in being profitable was the last item influencing export activities.

Yazdi et al. (2014) presented an empirical investigation to detect important factors influencing exporting herbal supplements. The study determined eight factors including supportive laws and regulations, organizational atmosphere, marketing structure, knowledge oriented, feasibility study, research and development, competitive strategy and partnership strategies influencing on export activities. Nikseresht (2013) considered whether or not improving relationships between countries positively could influence on empowering firms and export capabilities. They also considered whether or not improving national strategies for developing exports positively influences on empowering firms and export capabilities. They reported that empowering small and mid-cap firms could contribute the whole economy through boosting export.

Azad et al. (2013) attempted to determine important factors impacting on insurance issued by export guarantee funds. They determined four factors including risk management, customer oriented, quality management and trade management. Rahchamandi and Fallahi (2014) studied the effects of outsourcing logistics on improvement of export activities in minerals firms in Iran. Using structural equation modeling, the study indicated that there had been a meaningful relationship between strategic orientations of exporters against outsourcing third part logistics (3PL) and basic and additional capabilities of 3PL. In addition, there was a meaningful relationship between basic capabilities of 3PL and competitive advantage of exporters but there was not any meaningful relationship between additional capabilities of 3PL and competitive advantage of exporters. Finally, there was a meaningful relationship between competitive advantage of exporters and performance of exports. Villar et al. (2014) investigated the effects of knowledge management on export activities.

\section{The proposed method}

This paper presents an empirical investigation to study the role of entry into regional markets in fulfilling brand promise. The study designs two questionnaires, one for measuring brand promise and the other for measuring export capabilities, in Likert scale and distributes it among 250 randomly selected producers who were involved in production and development of various products in city of Tehran, Iran. Fig. 1 demonstrates personal characteristics of the participants.

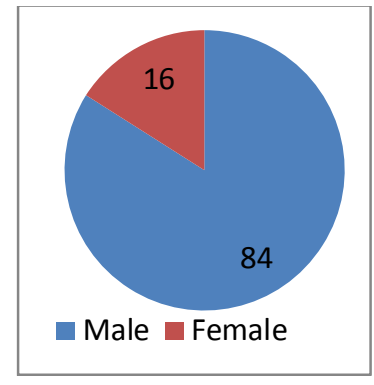

Gender
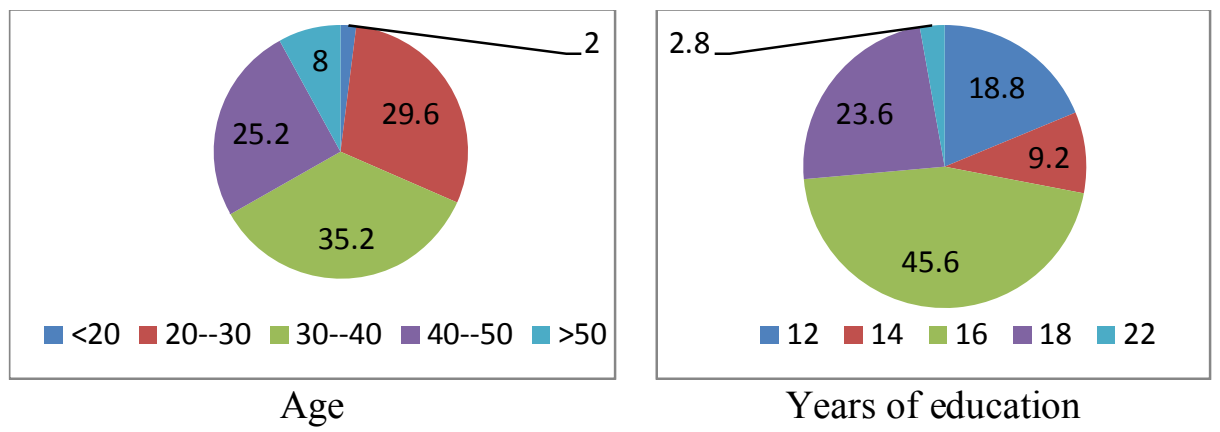

Years of education

Fig. 1. Personal characteristics of the participants

As we can observe from the results of Fig. 1, most people who participated in our survey were middle-aged male. In addition, they were highly educated since nearly $80 \%$ of them had some university educations. The study uses principal component analysis and Table 1 demonstrates the results of our survey. 
Table 1

The summary of principle component analysis

\begin{tabular}{|c|c|c|c|c|c|c|c|c|c|}
\hline \multirow[b]{2}{*}{ Factor } & \multicolumn{3}{|c|}{ Eigenvalue } & \multicolumn{3}{|c|}{ Extracted } & \multicolumn{3}{|c|}{ Extracted after rotation } \\
\hline & Variance & $\%$ Variance & Accumulated & Variance & $\%$ Variance & Accumulated & Variance & $\%$ Variance & Accumulated \\
\hline 1 & 7.198 & 19.453 & 19.453 & 7.198 & 19.453 & 19.453 & 4.242 & 11.464 & 11.464 \\
\hline 2 & 3.793 & 10.252 & 29.705 & 3.793 & 10.252 & 29.705 & 3.174 & 8.577 & 20.041 \\
\hline 3 & 2.719 & 7.349 & 37.054 & 2.719 & 7.349 & 37.054 & 2.52 & 6.81 & 26.852 \\
\hline 4 & 1.815 & 4.905 & 41.959 & 1.815 & 4.905 & 41.959 & 2.298 & 6.211 & 33.063 \\
\hline 5 & 1.643 & 4.44 & 46.399 & 1.643 & 4.44 & 46.399 & 1.945 & 5.256 & 38.319 \\
\hline 6 & 1.427 & 3.857 & 50.256 & 1.427 & 3.857 & 50.256 & 1.847 & 4.992 & 43.311 \\
\hline 7 & 1.283 & 3.467 & 53.722 & 1.283 & 3.467 & 53.722 & 1.817 & 4.911 & 48.223 \\
\hline 8 & 1.204 & 3.254 & 56.977 & 1.204 & 3.254 & 56.977 & 1.815 & 4.906 & 53.129 \\
\hline 9 & 1.127 & 3.047 & 60.024 & 1.127 & 3.047 & 60.024 & 1.792 & 4.843 & 57.971 \\
\hline 10 & 1.057 & 2.858 & 62.882 & 1.057 & 2.858 & 62.882 & 1.597 & 4.315 & 62.287 \\
\hline 11 & 1.017 & 2.75 & 65.631 & 1.017 & 2.75 & 65.631 & 1.238 & 3.345 & 65.631 \\
\hline 12 & 0.899 & 2.429 & 68.061 & & & & & & \\
\hline 13 & 0.829 & 2.24 & 70.301 & & & & & & \\
\hline 14 & 0.811 & 2.192 & 72.492 & & & & & & \\
\hline 15 & 0.781 & 2.11 & 74.602 & & & & & & \\
\hline 16 & 0.71 & 1.92 & 76.522 & & & & & & \\
\hline 17 & 0.678 & 1.834 & 78.355 & & & & & & \\
\hline 18 & 0.656 & 1.772 & 80.127 & & & & & & \\
\hline 19 & 0.638 & 1.726 & 81.853 & & & & & & \\
\hline 20 & 0.631 & 1.707 & 83.559 & & & & & & \\
\hline 21 & 0.549 & 1.484 & 85.044 & & & & & & \\
\hline 22 & 0.541 & 1.463 & 86.506 & & & & & & \\
\hline 23 & 0.513 & 1.387 & 87.894 & & & & & & \\
\hline 24 & 0.501 & 1.355 & 89.248 & & & & & & \\
\hline 25 & 0.486 & 1.312 & 90.561 & & & & & & \\
\hline 26 & 0.44 & 1.19 & 91.751 & & & & & & \\
\hline 27 & 0.418 & 1.13 & 92.881 & & & & & & \\
\hline 28 & 0.392 & 1.059 & 93.94 & & & & & & \\
\hline 29 & 0.383 & 1.036 & 94.976 & & & & & & \\
\hline 30 & 0.365 & 0.988 & 95.963 & & & & & & \\
\hline 31 & 0.347 & 0.937 & 96.901 & & & & & & \\
\hline 32 & 0.317 & 0.856 & 97.757 & & & & & & \\
\hline 33 & 0.254 & 0.688 & 98.445 & & & & & & \\
\hline 34 & 0.227 & 0.614 & 99.059 & & & & & & \\
\hline 35 & 0.168 & 0.453 & 99.512 & & & & & & \\
\hline 36 & 0.101 & 0.272 & 99.784 & & & & & & \\
\hline 37 & 0.08 & 0.216 & 100 & & & & & & \\
\hline
\end{tabular}

In addition, Fig. 1 demonstrates the results of Scree plot. According to the results of plot, we may extract seven factors. Moreover, Table 2 demonstrates the results of factors loading along with details of each group.

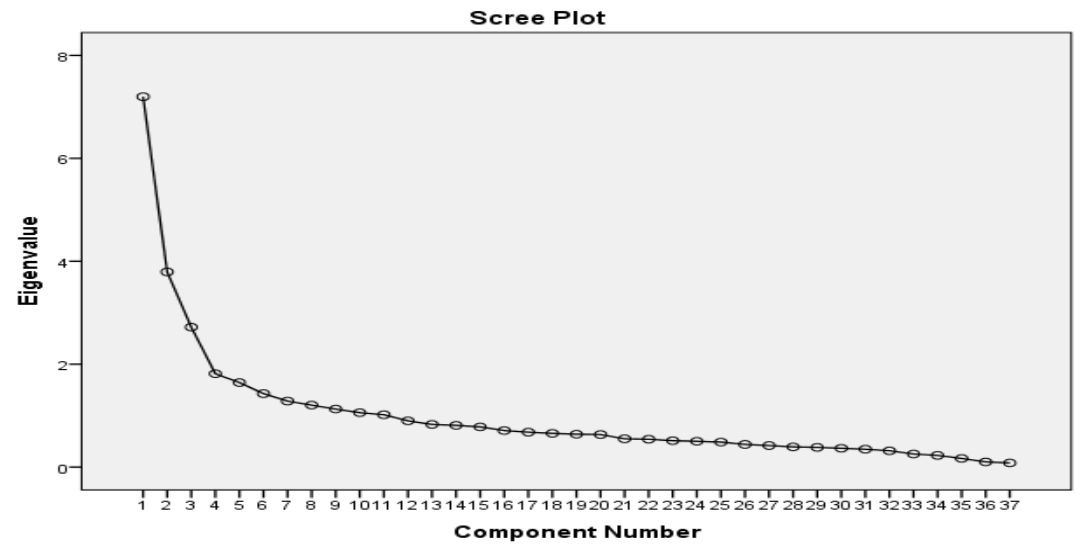

Fig. 2. The results of Scree plot 


\section{Table 2}

The summary of factors loading

\begin{tabular}{|c|c|c|c|}
\hline Factor & Question & Description & Factor loading \\
\hline \multirow{9}{*}{$\begin{array}{l}\text { Product } \\
\text { development }\end{array}$} & $\mathrm{q3}$ & Research and development & 0.729 \\
\hline & q6 & Innovation in production & 0.705 \\
\hline & q7 & Product life cycle & 0.699 \\
\hline & $\mathrm{q} 2$ & Advanced technological adaptation & 0.686 \\
\hline & $\mathrm{q} 1$ & High quality & 0.646 \\
\hline & q5 & Compatibility of market with product & 0.629 \\
\hline & $\mathrm{q} 4$ & Product diversity & 0.562 \\
\hline & q8 & Packaging & 0.497 \\
\hline & $\mathrm{q} 22$ & Custom rates & 0.792 \\
\hline \multirow{4}{*}{ Government } & $\mathrm{q} 23$ & Subsidy for export encouragement & 0.724 \\
\hline & q19 & Tax exemption & 0.693 \\
\hline & q20 & Government support from industry & 0.685 \\
\hline & $\mathrm{q} 18$ & Currency policy & 0.594 \\
\hline \multirow{4}{*}{ Strategic } & $\mathrm{q} 25$ & International fair participation & 0.86 \\
\hline & $\mathrm{q} 13$ & Strategic merger & 0.747 \\
\hline & q26 & Integrated marketing strategies & 0.586 \\
\hline & q14 & Pricing strategies & 0.561 \\
\hline \multirow{3}{*}{ Customer } & $\mathrm{q} 33$ & After sales services & 0.731 \\
\hline & $\mathrm{q} 37$ & Customer relationship channels & 0.644 \\
\hline & $\mathrm{q} 34$ & Market segmentation & 0.562 \\
\hline \multirow{3}{*}{ competitive } & $\mathrm{q} 16$ & International competition & 0.655 \\
\hline & q15 & Competition diversity & 0.584 \\
\hline & q9 & Market share & 0.476 \\
\hline \multirow{3}{*}{$\begin{array}{c}\text { Organizational } \\
\text { orientation }\end{array}$} & $\mathrm{q} 38$ & Research for marketing & 0.715 \\
\hline & q39 & Management commitment for export & 0.713 \\
\hline & $\mathrm{q} 40$ & Human resources & 0.581 \\
\hline \multirow{3}{*}{$\begin{array}{l}\text { Distribution } \\
\text { strategies }\end{array}$} & $\mathrm{q} 30$ & Foreign sales units & 0.731 \\
\hline & q29 & Distribution ownership & 0.591 \\
\hline & $\mathrm{q} 31$ & e-commerce & 0.575 \\
\hline
\end{tabular}

According to the results of Table 2, there are seven main factors influencing on the success of export development including product development, public advocacy, strategic orientation, customer satisfaction, competitive pressures, organizational capabilities and distribution strategies. We have also performed Spearman correlation test between brand promise and these seven factors and Table 3 shows details of our findings.

\section{Table 3}

The summary of Spearman correlation test

\begin{tabular}{lcccc}
\hline Relationship & r & Sig. & Level & Result \\
\hline Product development has meaningful relationship with brand promise & 0.501 & .000 & 0.05 & Confirmed \\
Competition has meaningful relationship with brand promise & 0.348 & .000 & 0.05 & Confirmed \\
Customer satisfaction has meaningful relationship with brand promise & 0.263 & 0.015 & 0.05 & Confirmed \\
Organizational capabilities has meaningful relationship with brand promise & 0.519 & 0.000 & 0.05 & Confirmed \\
Distribution channels has meaningful relationship with brand promise & 0.124 & 0.198 & 0.05 & Not Confirmed \\
Strategic orientation has meaningful relationship with brand promise & 0.455 & 0.007 & 0.05 & Confirmed \\
Government support has meaningful relationship with brand promise & 0.087 & 0.211 & 0.05 & Not Confirmed \\
\hline
\end{tabular}

The results of the implementation of Spearman test confirm the effects of five factors including product development, competition, customer satisfaction, organizational capabilities and strategic orientation. However, the effects of distribution channels and government support have not been confirmed. In our survey, organizational capabilities had the highest positive impact followed by product development and strategic orientation. We have performed stepwise regression technique and Table 4 shows the results of our survey. 
Table 4

The summary of stepwise regression technique

\begin{tabular}{lccccc}
\hline Variable & Coefficient & Standard value & Standard coefficient & t-value & Sig. \\
\hline Intercept & 60.114 & 3.091 & & 21.996 & 0.000 \\
Organizational capabilities & 0.598 & 0.213 & 0.398 & 3.937 & 0.003 \\
Product development & 0.577 & 0.181 & 0.320 & 3.545 & 0.012 \\
Competition & 0.425 & 0.126 & 0.284 & 3.201 & 0.006 \\
\hline
\end{tabular}

The results of Table 4 have also confirmed the positive effects of organizational capabilities, product development and competition when the level of significance is five percent.

\section{Conclusion}

In this paper, we have presented an empirical investigation to study the effects of different factors on brand promise in exporting goods in regional countries in Middle East. The using principle component analysis, the study has extracted seven factors and the implementation of Spearman correlation and stepwise correlation have confirmed that organizational capabilities, product development and competition have maintained positive impacts on brand promise on regional countries surrounded Iran. The results of our study are somehow consistent with other studies accomplished in other countries (Sousa \& Bradley, 2008; Stoian et al. 2011; Chi \& Sun, 2013).

\section{Acknowledgement}

The authors would like to thank the anonymous referees for constructive comments on earlier version of this paper.

\section{References}

Auttarapong, D. (2012). Package design expert system based on relation between packaging and perception of customer. Procedia Engineering, 32, 307-314.

Azad, N., Abbaszadeh, V., Rikhtegar, M., \& Asgari, M. (2013). An empirical investigation on factors influencing on electronic banking for developing export. Management Science Letters, 3(6), 15831586.

Chi, T., \& Sun, Y. (2013). Development of firm export market oriented behavior: Evidence from an emerging economy. International Business Review, 22(1), 339-350.

Chou, M. C., \& Wang, R. W. (2012). Displayability: An assessment of differentiation design for the findability of bottle packaging. Displays, 33(3), 146-156.

Filatotchev, I., Liu, X., Buck, T., \& Wright, M. (2009). The export orientation and export performance of high-technology SMEs in emerging markets: The effects of knowledge transfer by returnee entrepreneurs. Journal of International Business Studies, 40(6), 1005-1021.

Hosseini, S., Hamedani, A \& Nikbakht, M. (2014). The effect of firm characteristics and the propensity to export decision in food industry. Management Science Letters, 4(6), 1161-1166.

Mohammadi, M., Hnzayy, S \& Azad, N. (2014). A study on packaging factors influencing on export development. Management Science Letters, 4(10), 2213-2220.

Nataghi, A \& Nasrabadi, A. (2014). Investigating the effect of ecommerce on export development of rose water and essences. Management Science Letters, 4(11), 2343-2350.

Nikseresht, F. (2013). How empowering small and mid-cap firms develops national exports. Management Science Letters, 3(10), 2661-2664.

Rahchamandi, E \& Fallahi, K. (2014). An investigation on logistics outsourcing on exports of minerals goods. Uncertain Supply Chain Management, 2(3), 163-166.

Sousa, C.M.P., \& Bradley, F. (2008). Antecedents of international pricing adaptation and export performance. Journal of World Business, 43(3), 307-320

Stoian, M.C., Rialp, A., \& Rialp, J. (2011). Export performance under the microscope: A glance through Spanish lenses. International Business Review, 20(2), 117-135. 
Villar, C., Alegre, J., \& Pla-Barber, J. (2014). Exploring the role of knowledge management practices on exports: A dynamic capabilities view. International Business Review, 23(1), 38-44

Yazdi, N., Naami, A \& Azad, N. (2014). An empirical investigation on factors influencing export of herbal supplements. Management Science Letters, 4(2), 347-352. 